\title{
PENGEMBANGAN BAHAN AJAR GEOMETRI FRAKTAL BERBASIS EKSPERIMEN UNTUK MENINGKATKAN KOMPETENSI MAHASISWA
}

\author{
Dwi Juniati dan I Ketut Budayasa \\ FMIPA Universitas Negeri Surabaya \\ email: dwi_juniati@yahoo.com
}

\begin{abstract}
Abstrak: Penelitian ini bertujuan untuk menghasilkan bahan ajar geometri fraktal yang berbasis eksperimen untuk meningkatkan kompetensi mahasiswa. Jenis penelitian adalah penelitian pengembangan. Model pengembangan yang digunakan adalah model Thiagarajan, Semmel, \& Semmel. Subjek penelitian adalah mahasiswa matematika Universitas Negeri Surabaya yang memprogram geometri fraktal. Bahan ajar yang dihasilkan adalah buku dan lembar kerja mahasiswa yang berbasis eksperimen. Kegiatan eksperimen yang dirancang berbasis data yang dijumpai di lapangan dan penggunaan teknologi multimedia yang berupa bermacam software dan penggunaan alat untuk pengukuran. Topik eksperimen yang diberikan adalah pembentukan spirolateral, pembentukan fraktal dengan menggunakan objek geometri klasik, pembentukan fraktal dengan sistem Lindenmayer, pembentukan Fraktal dengan sistem fungsi teriterasi, penghitungan dimensi fraktal dan aplikasinya. Teknik pengumpulan data lewat angket dan pengamatan; data dianalisis secara kualitatif dan teknik statistik deskriptif. Hasil penelitian menunjukkan bahwa bahan ajar yang dihasilkan memenuhi kriteria valid, praktis dan efektif.
\end{abstract}

Kata Kunci: Geometri Fraktal, pembelajaran berbasis eksperimen, pengembangan bahan ajar

\section{DEVELOPING EXPERIMENT-BASED TEACHING MATERIALS OF FRACTAL GEOMETRY TO UPGRADE STUDENTS' COMPETENCIES}

\begin{abstract}
This study was aimed at producing experiment-based teaching materials of fractal geometry in order to improve students' competence. Development research model proposed by Thiagarajan, Semmel \& Semmel was adopted. The subjects were mathematics students of Universitas Negeri Surabaya taking Fractal geometry course in 2015/2016 academic year. Teaching materials included lecture books and students' worksheets containing experiment activities. Experiments were conducted using open source software and measurement tools. Experiment topics comprised spirolateral construction, fractal construction with iterated function system, Fractal dimension calculation methods and their applications. The results of this study showed that the teaching materials were valid, practical and effective.
\end{abstract}

Keywords: Fractal Geometry, learning by experiments, development of teaching materials

\section{INTRODUCTION}

Efforts to improve the quality of education have been continuously carried out thoroughly including the aspects of knowledge, skills, attitudes and values. An effort of quality improvement is a change in new curriculum namely KKNI-based curriculum. One Description of Level 6 that must be fulfilled by a study program similar to D4 or S1 based on KKNI is that the graduates are able to apply their expertise and make use science, technology, and / or art in its field in problem solving and able to adapt to the situation at hand. However, in reality, there are still a lot of math students that do not know how to utilize mathematical theories learned to solve the problem or how to apply the theories learned in college. Therefore, a learning strategy that can provide a direct experience to students by introducing, familiarizing and training students to apply mathematical theories acquired in solving problemsis needed. One of strategies that can be used in learning to solve it is learning by experimental method. This is consistent with the research results of Davidovitch et al (2014: 145), which concluded that learning which facilitated student learning based on 
experience and conducting experiments helped students understand the material intensively and make students ready to deal with non-routine problems.

One of the existing courses in the study program of mathematics Unesa is Fractal Geometry. Fractal geometry helps explain a lot of things or situations that are hard to describe simply by using the Euclidean geometry, for example, the mountain is not the form of a cone, the shoreline is not a straight line and the surface of the earth is not spherical. This theory has been widely applied in science, technology, and art works of the computer, including batik fractal. The characteristic of Fractal geometry changing the way of mathematicians is the dimension of fractal objects that can be a fraction number. It is different from thetopology dimensions of an object that is always a positive integer or non-negative integer (Falconer, 2013). This may be due to many things in life that have a dimension in the form of a fraction, for example, a sponge for washing dishes or cotton is not a three-dimensional because every small part of it always contains a cavity filled with air so that it has dimension Fractal between 2 and 3 depending on the density. The more dense of the sponge, the dimension is closer to three. So Fractal dimension gives a new insight in looking at the world in mathematics view. In addition another characteristic of fractals is the nature of self-similarity at different scales. Because of its beauty, fractal is widely used in computer graphics to create new natural forms or even amazing natural surface that is often called a fractal landscape, as has been widely used in movies like Star Trek and Star Wars movies. In addition by using the geometry characteristics, a variety of complex shapes which have been utilized in the manufacture of computer games can be made as it is written in the article of Gharehchopogh F. S. et al (2014: 15).

One of the learning methods that gives concrete experiences in the learning process is a experiment-based learning method. The experiment learning model or experiment-based learning is a form of learning that is introduced by David Kolb. According to Kolb (2015: 37) and Ramamurthy (2006), the characteristics of the experimental based learning are: (1). Learning is a process rather than output, meaning that the emphasis of the experiment-based learning is the process passed by the students when they are learning, not only the final result. (2). Learning is a continuous process based on an experience, which means that knowledge gains the experience of the learner. (3). The learning process requires a resolution of the conflict between abstract concepts and concrete experience, which means learning needs a process where learners can use the theories or concepts that the master to deal with concrete problems encountered. By conducting experiments, students are expected to apply the theory learned through reflective observation, as well as the forming conceptualization abstractly.

Fractal Geometry studies about geometry objects that is self resemblance and fractional dimensions, so it can broaden the students' view to understand that mathematics is growing and changing. Formerly, they learn that dimension is always an integer but now it can change, and it provides opportunities for students to investigate and describe the relationship between geometry and algebra. According to Yi (2004), teaching the concept of fractal takes a lot of activities so that students can be involved in drawing various fractal shapes, in giving reasons and thinking mathematically. The procedure in learning fractal geometry must involve a lot of observations and construct fractal shapes because students will understand more math concepts in fractal geometry if they can see the procedure of establishing a fractal object step by step and connect it with theories or concepts they are learning. In addition, the results of research conducted by Abu-Elwan (2014), also showed that the fractal geometry conducted by the experimental group and skills training of fractal formation provide an improvement in students' geometry reasoning skill. Based on those opinions, the Kolb experiment-based learning method is suitable in teaching of fractal geometry. By doing an experiment using some software, students can form various fractal objects and test the theory learned in forming objects. To carry out such study, teaching materials that support the concepts establishment and application through experiment activity is needed. Therefore, the teaching material development of experiment- based fractal geometry is indispensable.

\section{METHOD}

This research is a development research. It was said development because this 
research was intended to produce experiment-based learning materials that met the valid, practical and effective criteria. The products that would be produced were the textbook and students worksheets(called LKM) in experiment based for fractal geometry.

The development model used was the model of Thiagarajan, Semmel \& Semmel (1974), which consisted of four stages, so-called "Four-D Model" (Model 4-D). The four stages were defining, design, developing and disseminating. The purpose of defining stage was setting and defining learning needs by analyzing the goals and the material limits. The activities undertaken at this stage included initial-final analysis, students analysis, material analysis and tasks analysis and learning objectives. In designing stage, designing the sample (prototype) of teaching material was done by selecting the format and the initial design of teaching materials. The format selection in teaching materials development included format selection for designing the content, the selection of learning strategies, strategy of experiments assignment and the use of learning resources in order to obtain Draft I. In development stage, modifying the learning equipment and research instruments, which had been generated on the initial design activities, was revised based on the input of experts and data obtained from field trials. The activities that needed to be done at this stage were experts assesment, limited testing and field testing. The experts assessment included content validity, language, display, equipment conformity with the objectives. After the draft I was validated and revised based on the judgement of experts, it became Draft II. Furthermore, the limited testing was done. Limited testing was conducted to obtain direct input in the form of responses, reactions, comments from students comment on learning equipment and instruments that had been arranged. Based on the limited testing revision was performed in order to obtain draft III. The equipments produced after limited testing was implemented in learning to see if the teaching materials produced met the valid, practical and effective criteria as prescribed in this study. The implementation result was analyzed, then revised. After it fulfilled the criteria, then Draft IV or the equipments that had been developed was gained.

The research instrument was a validation sheet, observation sheet and students' questionnaire. Validation was done to look at the validity of the textbook in terms of both the constructs and the language aspects, as well as the format aspect that includes student worksheets (LKM) completeness, clarity of writing format, the attraction of LKM display, the content aspect of LKM including suitability of LKM with the purpose, suitability of LKM with the material, suitability of duty in LKM with the experimental activities and objectives as well as thelanguage used in terms of the suitability with the rules of Indonesian, the language simplicity, suitability meaning of language for students. The assessment consisted of grades 1 to 5 with a rating scale of 1: bad, 2: poor, 3: pretty good, 4: Good, 5: Excellent. To know the responses of students, a questionnaire was created that aimed to investigate the students' response, opinions and suggestions toward the instructional materials used. The implementation of teaching materials is known from the observation sheet that aimed to see the activeness and the ability of students in understanding the teaching materials, conducting experiments and communicating the results of the experiment.

The Criteria of success in this research are: the teaching material was valid if the validation result from the experts on all the equipments to every aspect was average of more than 3 of the score $1-5$, and was eligible to be used in a limited test. The equipment was practical if the activities of students in learning was effective that was if more than $50 \%$ of the students were actively involved in every activity, more than $50 \%$ of the students were able to communicate their opinions and more than $50 \%$ of the students had the ability to choose software or method that corresponded to the context of the problem and the students' responses were positive that was more than $75 \%$ of students responded "agree" to the positive statement. The teaching material was effective if the data analysis of the implementation results showed that the ability of students in doing experiments had "good" criteria. The ability of students in doing experiments was said to be good if: (1). More than $50 \%$ of students could complete any task of experiments given. (2). more than $50 \%$ of the students were actively involved in the experiment, understood what they did and could communicate the results. (3). more than $50 \%$ of the students were able to use and explain the method or strategy used in completing the given task. 
The research subjects were math students of Surabaya State University who took Fractal geometry course in the academic year 2015/2016.

\section{RESULT AND DISCUSSION}

The results of the study given in the following are the steps or stages done starting from the defining stage, designing stage and developing stage.

\section{Defining Stage}

The activities that were done at this stage included initial-final analysis, analysis of students, material analysis and tasks analysis and learning objectives. In the initial stage, curriculum analysis was done, where the students took geometry Fractal course in the 6th semester and they had completed the subjects of geometry and programming language, computer science and complex analysis, so that it could be used as a basis in arranging objectives and learning achievements and also the activity of designing

experiments aided by various software and material to be covered adapted to the material already learned by the students. In addition, to meet the goals that expected the students to have the ability to resolve the problems encountered by using the theory learned, it needed an appropriate approach. One of the appropriate approaches was an experiment-based approach. This approach is also in accordance with Kuh (Kuh et al, 2010: 8) who stated that the more important for students was what they did more than what they learned. This was also consistent with the results of Mulbar's research (2013: 420) which concluded that the use of learning models that optimized the activity and creativity would give a positive impact on the success of one's learning.

\section{Designing Stage}

At this stage, the prototype of teaching materials was designed as textbooks and experiment- based students' worksheets, conducted with the format selection and topic of discussion and also experiment activities. The experiment activities selected were determined based on the literature study result of some applications of the fractal theory, including the application of fractal dimension used to analyze the seismic activity of land in Mexico conducted by JP Ortiz et al (Ortiz et al, 2016). JA Ramirez et al also analyzed an evolution from a Jackson Pollock painting based on a fractal pattern, where the painting produced used a unique painting technique (Ramirez et al, 2016). The experiment activities also paid attention on the research of A. Pogoy stating that mathematical performance in learning fractal was strongly influenced by the cognitive domain and learning content, in which the cognitive domain that was meant was knowing, applying, and reasoning (Pogoy et al, 2016). At this stage, a textbook which consisted of 6 chapters and students' worksheets consisting of 8 chapters were produced. Students' Worksheet was designed to give experiment assignments to students created gradually by performing experiments so that students could apply the theory learned. In addition experiment was also designed to utilize the similar technology in the form of free software that could be chosen by the students when doing experiments. Some software that could be selected was L-system software, Ultra Fractal, Fractal grower, IFS Kit, Brice, etc.

\section{Developing Stage}

At this stage, teaching materials and research instruments, which had been generated on the initial design activities, were revised based on the input of experts and data obtained from field trial.

Based on the above activities, acquired textbooks and worksheets were described below.

Textbooks produced consisted of 6 chapters, can be seen in Juniati, (2016), namely:

Chapter 1. Fractal Geometry

This chapter discussed the origin of the emergence of fractal theory along with the characteristics and various applications that had been produced and could be found in life using fractal characteristics.

Chapter 2. Iteration using classical geometry object

This chapter contained the types of pattern formation of Fractal structure using classical geometry objects, such as lines, curves, two and three dimensional figureof geometry. Besides it also discussed about spirolateral, a method of forming a geometric representation of a number sequence code followed by a representation geometric of a name. 
Chapter 3. Lindenmayer System (L-System)

This chapter discussed the origin of Lindenmayer system theory emergence, the formation process, the types and the characteristics and also the formation examples of fractal objects with Lindenmayer system and the iteration result by using some Lindenmayer software.

Chapter 4. Formation of Fractal with IFS (Iteration Function System)

This chapter contained the various transformation functions, the transformation representation in the form of a matrix and its characteristics. How to determine the result of the transformation, and the formation of fractal objects was by using the system of transformation function with iteration, the kinds of transformations that were used and the examples of various iteration results by using some software. How the iteration of transformations functions can form the beautiful forms.

\section{Chapter 5. Fractal Dimension}

This chapter contained a variety of methods to determine the fractal dimension and the characteristics of each method and examples. The methods discussed included self similarity dimension, box counting dimension, Richardson dimension, exponent Hurst dimension. The materials were about calculating the dimensions of the various Fractal geometry objects using several methods including fractal dimension calculating of real objects such as fractal dimension of tissue, soil, paper and bread.

\section{Chapter 6. Landscape Fractal}

This chapter consisted of the principles and methods used in forming the landscape Fractal and the formation process.

Experiments on LKM were designed such that by carrying out the given activity was expected that students were able to reflect the theory and apply it in solving problems.

Topics in LKM (Students' Worksheet) which were generated were divided into eight topics, namely:

\section{LKM 1. Spirolateral}

Spirolateral was a method of geometric shapes depiction of numbers sequence or letters converted to numbers iteratively.

For example, the geometric shape of "ANDRE" is

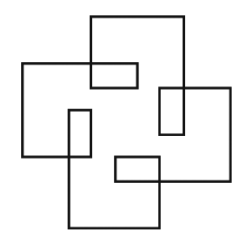

Figure 1. The spirolateral geometric shapes of the word "ANDRE".

Students were asked to describe the geometric shape of a given sequence numbers, a given names and then made the geometric shape of the group members' names. From the test results, it was obtained that all students could fullfill the spirolateral tasks assigned.

LKM 2. Formation of Fractal objects using classical geometry objects

Through Euclide geometry object such as line segments, triangles, a square and a circle, students were expected to be creative to form fractal objects through an iteration process. All students were able to complete this task. The following images are generated by the students.

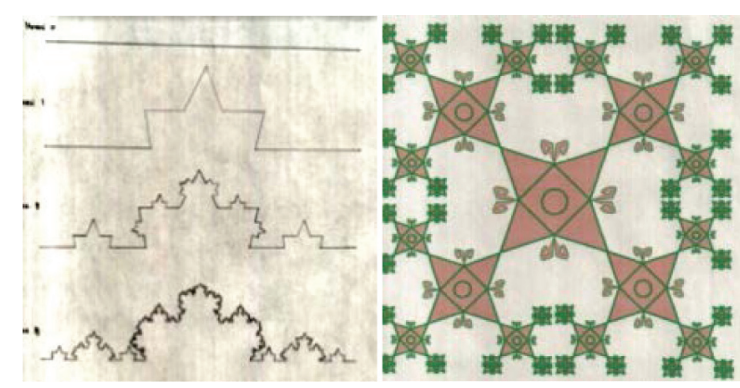

Figure 2. Fractal Formation through iteration of the line segment and two dimensional figure.

LKM 3. Formation of Fractal objects using Lindenmayer system (part 1)

Lindenmayer System is a language consisting of the alphabet or symbols (string), a set of rules that can expand a symbol into some larger symbols (string), an initial axiom indicating the beginning of construction, as well as a mechanism to translate the generator string to a geometric structure form. If $F$ states move 1 unit and + gives direction to turn left $90^{\circ}$ and - states turn right $90^{\circ}$ then geometric shape of F+F-F-F+F is described as follows.

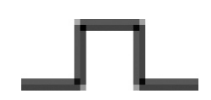

Figure 3. The geometric shape of $F+F-F-F+F$. 
Students were asked to form an object from Lindenmayer system supplied with the results of iteration and then the students did the experiment in determining Lindenmayer system from Fractal object given. The implementation result showed that more than $75 \%$ of students could accomplish this task.

LKM 4. Formation of Fractal object with Lindenmayer system (part 2)

Students were asked to determine Lindenmayer system of objects that were more complicated than previously, that was determining the Lindenmayer system of kenikir leaves in the shape like the letter " $S$ " that was turning left and right. Next the students were asked to determine the objects that were found in the field to be determined the Lindenmayer system. To determine Lindenmayer system of kenikir leavesshaped "S", at first only $60 \%$ of the students who fulfilled it, the other students found difficulty in determining how to make a system of iteration so that the directions result form of iteration turn. After being inserted the additional task to form an object that turned the direction and observed changes obtained by changing the degree of the angles, then more than $75 \%$ students could fulfill this task. While for the task of determining the objects that were found in the field to determine the system, most students chose the object of plants such as flowers, coconut trees, banyan tree, celery leaves, although some also chose inanimate objects such as tires, fan, net, or paving. Here is the students' experiment result as a formed image, the result of iteration and Lindenmayer system used to shape it.

a. Lavender Tree

Lindenmayer System of Lavender tree is the following.

Axiom: FFX

Rules: $\mathrm{F}=\mathrm{FF}-[-\mathrm{FF}-\mathrm{F}]+[++\mathrm{FF}+\mathrm{F}] ; \mathrm{X}=\mathrm{FFF}+[+\mathrm{F}]+[-$ $\mathrm{FF}]$

angle: $15^{\circ}$ (Figure 4 )

b. Coconut tree

Lindenmayer System of coconut tree is as the following.

Axiom: !!!![-fffa]ff[++fffc]ff[--fffb][+fffa][--fffa]

$[+++$ fffd $]$ fffd

Rules: $\mathrm{a}=\mathrm{aa}[+\mathrm{fffff}+\mathrm{fff}+\mathrm{f}] \mathrm{f}[-\mathrm{fffff}-\mathrm{fff}-\mathrm{f}] \mathrm{fa}$

$b=b[+f f f f f+f f f+f]-f c[-f f f f f-f f f-f] f b$

$\mathrm{c}=\mathrm{c}[+\mathrm{fffff}+\mathrm{fff}+\mathrm{f}]+\mathrm{f}[-\mathrm{fffff}-\mathrm{fff}-\mathrm{f}] \mathrm{fc}$

$\mathrm{d}=\mathrm{a}[+\mathrm{fffff}+\mathrm{fff}+\mathrm{f}]$-f[-fffff-fff-f]fc--a

Angle: $20^{\circ}$ (Figure 5)

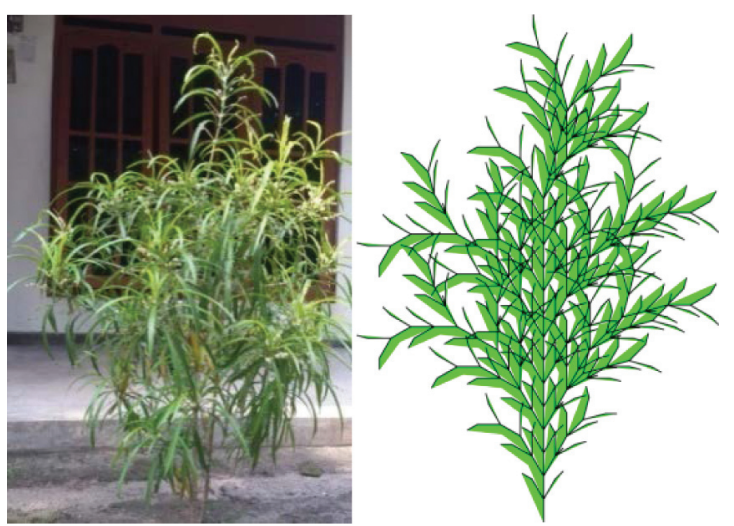

Figure 4. Figure of Lavender tree and the result form of Lindenmayer system.

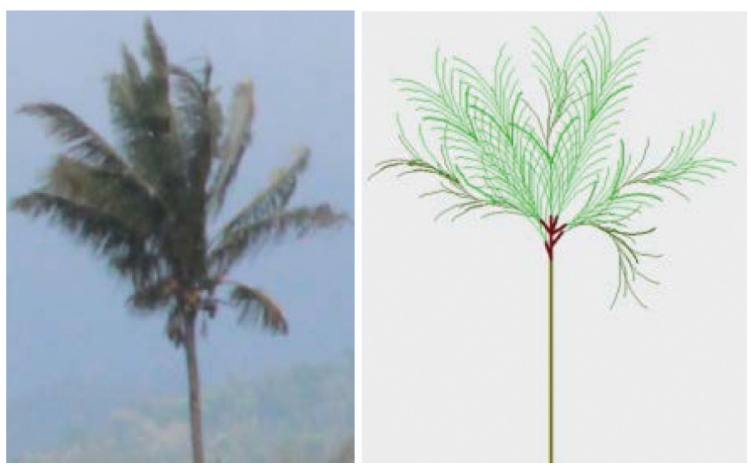

Figure 5. Figure of coconut trees and formation result of Lindenmayer system.

\section{LKM 5. Iterated function system}

Students were asked to do an experiment with one software chosen to determine the functions of transformation needed to form a variety of objects given. Overall, students could fulfill this task well. They used different methods. There were students determining by trial and error, there were using of geometry analysis based on location changes, size and shape, then they determined the transformation function.

At LKM 6, students were asked to specify the iteration function system of fractal objects given where the object was more complex than in the previous task. Then the students were asked to form a variety of art objects or images using the iteration function system. Various objects were selected by the students to be formed using iteration function systems, for example, a fan shape, trees, flowers and so on. Here is an example of an object tree formed by the students using transformation iteration in the form of dilatation, rotation and translation in a photograph. The functions used to form the tree are three functions namely $\mathrm{f} 1, \mathrm{f} 2$ and $\mathrm{f} 3$. 
f 1: Dilatation function with center $\mathrm{O}(0,0)$ with a 0.3 scale; as well as the rotation angle $\theta=45^{\circ}$ and translation with vector $\left(\begin{array}{c}0,24 \\ 0\end{array}\right)$

f_2: Dilatation function with center $\mathrm{O}(0,0)$ with a 0.3 scale; as well as the rotation angle $\theta=-45^{\circ}$ and translation with vector $\left(\begin{array}{c}0,5 \\ 0,235\end{array}\right)$.

f_3 : Dilatation function with center $\mathrm{O}(0,0)$ with scale $(0.5,0.728)$ and translation with vector $\left(\begin{array}{l}0,24 \\ 0,25\end{array}\right)$

Using the IFT Kit software, students could describe the result of iteration as follows.

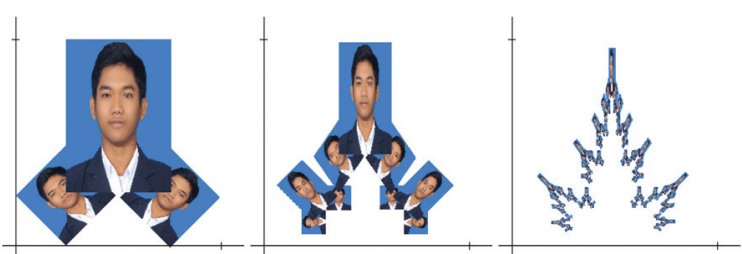

Figure 6. Figure of tree formations results through function iteration.

At LKM 7, students were asked to determine the dimensions of various fractal objects like Fractal dimension of Gasket Apollo, fractal dimension of the island outline of Sulawesi, fractal dimension of Mandelbrot set, Fractal dimension of stock price of a company and analyzing the condition of a company based on the fractal dimension of stock price. The students were also asked to specify objects found in the field to determine the fractal dimension.

Based on the implementation, it was found that all students could accomplish this task very well by doing experiments using software that they chose. Objects selected by students to specify the dimension were papaya leaf, cassava leaf, lamtoro leaf and so forth.

At LKM 8, the students were asked to determine the dimensions of real objects, such assoil, tofu, bread,cake, cotton, and so on. Based on the experimental results of students, it was known that the dimension of Gresik land was 2.478; dimension of clay was 2,091 and the dimension of soil in UNESA was 2.271, while the fractal dimension of yellow tofu was 2.439; the fractal dimension of white tofu was 2.131.

Based on the implementation, all students by doing experiments could accomplish this task very well.

\section{The validation result}

The valuators consisted of three mathematics professors and 3 students. The validation process results were as follows: format aspect that included LKM completeness got score 5 (very good) from all valuators, clarity of writing format got score 5 (very good) from 5 valuators and 1 valuator gave score 4 (good), the performance of LKM got score from 4 valuators and 2 valuator gave score 4 (good). The content aspect of LKM which included the suitability of LKM with the goal, got score 5 (very good) from all valuators, the suitability of LKM with the material got score 5 (very good) from all valuators, while the suitability of assignment in LKM with experiment activities and goals got score 5 (excellent) from 4 valuators, and 2 valuators gave score 4 (good). The language aspect used in terms of suitability with the rules of Indonesian got score 5 (very good) from 4 valuators, and 2 valuators gave score 4 (good), the simplicity of the language got score 5 (very good) from all valuators, while the suitability of the language meaning for student got score 5 (very good) from all valuators.

\section{Observation result}

Observation was done in every activity and the aspects observed were the students' activeness, the ability of expressing ideas, the ability to select and use the corresponding software, the ability to do experiment, to understand the experiment conducted to complete the task, as well as the ability to determine and explain the strategy and method used.

The observation provided the result that the material fulfilled the criteria of a practical, because more than $50 \%$ of the students were actively involved in every activity, more than $50 \%$ of the students were able to communicate their opinions and more than $50 \%$ of the students had the ability to choose software or method that corresponded to the context of the problem and more than $75 \%$ of students give the positive response about the learning process, learning methods and the teaching materials.

The equipment was effective because the ability of students to do experiments fulfilled good criteria, namely more than $50 \%$ of students could complete any task of experiment given, more than $50 \%$ of the students were actively involved in the experiment. They understood what they did and communicated the results, as well as more than 
$50 \%$ of students were able to use and explain the method or strategy used in completing a given task.

Here is observation recapitulation result, provided the sign number corresponding to each statement is as follows:

1: if the percentage of students who meet the statement $\leq 25 \%$

2: if $25 \%<$ percentage of students who meet the statement $\leq 50 \%$
3: if $50 \%<$ percentage of students who meet the statement of $\leq 75 \%$

4: if $75 \%<$ percentage of students who meet the statement $\leq 100 \%$

Based on the students' response data recapitulation every positive statement was responded to at least $90 \%$ by students. In other words the student's response was positive.

It can be seen from the results recapitulation of students' responses given below.

Table 1. Observation Table of students' activities

\section{Rated aspect}

assessment activity at the meeting to

I Students' Activity

Students are actively involved in learning

$\begin{array}{llllllll}1 & 2 & 3 & 4 & 5 & 6 & 7 & 8\end{array}$

Students are able to communicate the results or opinions

Students have the ability to choose software or methods appropriate to the context of the problem

$\begin{array}{llllllll}4 & 4 & 4 & 4 & 4 & 4 & 4 & 4 \\ 4 & 3 & 4 & 4 & 4 & 4 & 3 & 3 \\ 4 & 4 & 4 & 4 & 4 & 4 & 3 & 3\end{array}$

II Competence in conducting experiments

Students demonstrate an understanding on a given experiment

$\begin{array}{llllllll}4 & 4 & 4 & 4 & 4 & 4 & 4 & 4\end{array}$

Students are able to use a certain strategy or method in completing experiment

Students are able to provide an explanation or excuse stages of the experiments conducted

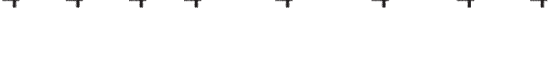

Students are able to complete the experiment given

$\begin{array}{llllllll}4 & 4 & 4 & 4 & 4 & 4 & 3 & 4\end{array}$

$\begin{array}{llllllll}4 & 4 & 4 & 4 & 4 & 4 & 3 & 4\end{array}$

$\begin{array}{llllllll}4 & 4 & 4 & 4 & 4 & 4 & 4 & 4\end{array}$

Table 2. Table of students' responses

\begin{tabular}{|c|c|c|c|}
\hline \multirow{2}{*}{ No. } & \multirow{2}{*}{ Statement } & \multicolumn{2}{|c|}{ Student Response } \\
\hline & & Agree & Disagree \\
\hline 1 & $\begin{array}{l}\text { Learning gives students an opportunity to conduct experiments to practice the } \\
\text { theory. }\end{array}$ & $95 \%$ & $5 \%$ \\
\hline 2 & $\begin{array}{l}\text { Learning using the method links theory and environmental conditions or the } \\
\text { field }\end{array}$ & $100 \%$ & - \\
\hline 3 & $\begin{array}{l}\text { Learning undertaken grows motivation in linking theory to problems in the } \\
\text { field or the environment }\end{array}$ & $100 \%$ & - \\
\hline 4 & Learning gives students the opportunity to find ideas to solve a problem & $97.5 \%$ & $2.5 \%$ \\
\hline 5 & $\begin{array}{l}\text { The task given is to encourage students to use the theory acquired to solve the } \\
\text { problems that are found in the neighborhood }\end{array}$ & $100 \%$ & - \\
\hline 6 & $\begin{array}{l}\text { Workingin teams to complete thelecture tasksin solving a problem makes } \\
\text { students accustomed to express ideas of a problem solution }\end{array}$ & $100 \%$ & - \\
\hline 7 & The task given is sufficiently clear. & $100 \%$ & - \\
\hline 8 & $\begin{array}{l}\text { Learning gives a new view about the application of mathematical theories } \\
\text { (fractal) in life }\end{array}$ & $100 \%$ & - \\
\hline 9 & $\begin{array}{l}\text { I am happy to follow the activities in the learning process of fractal geometry } \\
\text { using the experimental approach and task-based field data. }\end{array}$ & $100 \%$ & - \\
\hline 10 & I want the other study also use a based experiments method & $100 \%$ & - \\
\hline
\end{tabular}




\section{Conclusions and suggestions}

Based on validation result, it is obtained that the teaching materials produced in the form of textbooks and Worksheet Students (LKM) have fulfilled valid criteria and for students' responses all aspects get a positive response. Based on the result of observations, it is known that LKM makes the students able to understand the teaching materials, conduct experiments and communicate the results. Students are able to form a variety of Fractal objects by doing experiments, and with the help of software chosen they are able to visualize as expected so in other words it can be said that competence of students increases with the success of completing the work and they can apply the theory acquired to solve the problem. Therefore it can be said teaching materials developed fulfill the valid, practical and effective criteria. The results of this study are in line with Leung (Leung, 2006) who states that the use of ICT in learning activities can have a positive impact in understanding the concept. In addition, research conducted by Lewis namely experimentbased learning to understand the concept of fractal dimension shows that students more easily grasp concepts by conducting experiments (Frame and Mandelbrot, 2002). Therefore it is suggested this method could be used to study other materials.

\section{THANK-YOU NOTE}

This article is one of the PUPT research results funded by IDB. Therefore the researcher would like to thank to IDB and Unesa that have provided assistance, as well as to all parties so that the research results in the form of this article can be completed. Thank also goes to the reviewer who gave feedback and suggestions and to the manager of scientific journal Cakrawala Pendidikan of Yogyakarta State University that has published this article.

\section{BIBLIOGRAPHY}

Abu-Elwan, R, 2014, "The Effect of Teaching of Chaos Theory and Fractal Geometry on Geometry Reasoning Skills of Secondary Students, International Journal of Research in Education Methodology, Vol. 6. No. 2.

Davidovitch, N., Yavich R, and Keller, N., 2014, "Mathematics and Experiential Learning: Are They Compatible?", Journal of College
Teaching \& Learning, Volume 11, Number 3 , The Clute institute.

Falconer, K, 2013, Fraktal Geometry: Mathematical Foundation and Applications, England, John Wiley and Sons.

Frame, M. and Mandelbrot, B., 2002, "Fractal, Graphics and Mathematics Education", MAA Notes.

Gharehchopogh, F. S., Maleki, I., Sadouni, S., 2014, Analysis of the Fractal Koch Method in Computer Games Development, International Journal of Computer Graphics \& Animation (IJCGA) Vol.4, No.1.

Juniati, D. and Budayasa, I. K., 2016, Geometri Fractal dan Aplikasinya, University Press, Surabaya.

Kolb, D. 2015, Experiential Learning: Experience as the Source of Learning and Development, Pearson Education Inc.

Kuh, G., Kinzie, J., Schuh, J. \& Whitt, E., 2010, "Student success in college: Creating conditions that matter", Jossey Bass.

Leung, F., K.,S., 2006, “The Impact of ICT Tools on Our Understanding of Nature of Mathematics", For The Learning of Mathematics, Vol. 26, No. 1.

Mulbar, U, 2013, "Pengembangan Model Pembelajaran Matematika dengan Memanfaatkan Sistem Sosial Masyarakat", Jurnal Cakrawala Pendidikan XXXII (3).

Ortiz, J. P., et al, 2016, Seismic Activity Seen Through Evolution of the Hurst Exponent Model In 3D, Fractals, Fractals, Vol. 24, No. 4.

Pogoy, A., Balo, V. T., Obaob Jr., Chiu, S., 2015, Fractal Correlations on Content and Cognitive Domains and Mathematics Performance Across Countries, European Scientific Journal, edition vol.11, No.16. 
Ramamurthy, R. And Reyes A. 2006, Experimental Learning. Michigan, USA, SAE Internasional.

Ramirez, J. A., et al., 2016, Fractal Analysis of Jackson Pollock's Painting Evolution, Chaos, Solitons and Fractals, No. 83, Elsevier.
Thiagarajan, S., Semmel, D.S., dan Semmel, M.I. 1974. Instructional Development for Training Teacher of Exceptional Children. Minnesota: University of Minnesota.

Yi, T. 2004, A Technology-Enhanced Fractal Chaos Course, Electronic Proceeding of the Seventeenth Annual International Conference on Technology in Colligate Mathematics, New Orleans. 